\title{
Helping the poor: The aid dilemma
}

\section{Yoksullara yardım etmek: Yardım ilkilemi}

\author{
Mehmet Cem MÜDERRİSOĞLUa
}

Did you know that almost half of the world lives on less than $\$ 2$ a day? (1). More surprisingly, the three richest people in the world have more wealth than 600 million people living in the world's poorest countries (ibid). These statistics undoubtedly show us that we live in a world characterised by serious inequality between the rich and poor. Some people, including Singer, point out the immoderate disparity between the rich and poor around the world and claim that it is the duty of the affluent to donate to overseas aid organisations (2). Others argue that any system of sharing that amounts to foreign aid from the rich nations to the poor ones creates problems, "bringing eventual ruin upon all who share in the commons" (3). In attempting to address this complex issue, this essay will analyse cases where it might be appropriate to provide direct monetary aid to poor countries and cases in which this financial help might be counterproductive, and then offers suggestions on how rich countries might help the poor ones overcome poverty-related problems.

It is well-known that poverty is one the world's most serious problems and many believe that it is a moral duty to help the poor nations that are caught in an emergency and suffer from catastrophic events such as famine, drought, or disease. For instance, in 2010, a devastating earthquake hit Haiti leaving 2,500 people dead and about 300,000 people wounded (4). Countless buildings collapsed and infrastructure systems were destroyed, which caused thousands of people to lose their homes and work places. Natural resources were also affected detrimentally. As a result, Haitian people faced the issue of satisfying their basic needs such as having safe water, food supply, and shelter with their lives being endangered to the point of needing the help of affluent nations help to survive. When a disaster such as this occurs, affluent individuals and nations should certainly contribute by, as Singer suggests, people should be ready to give some of their wealth to those less fortunate (2). It is not easy to make an absolute statement about how people should help, but most would agree that there are extreme situations where everyone needs to help financially by donating funds or sending humanitarian supplies to charitable organisations.

The fact that poor nations need help in urgent cases and should not be subjected to punishment for a crime they did not commit is understandable and may be connected to our humanitarian impulses. However, the issue of financial aid should be questioned as sometimes good deeds have bad consequences in the long run. Constantly providing those poor countries with financial help does not solve povertyrelated problems, but can sometimes make the situation worse both for the rich countries as well as the poor ones. As stated by Hardin, the population of Ecuador, Venezuela, Pakistan, and several other countries are increasing at a rate of $3.3 \%$ per year, whereas this rate is only $0.8 \%$ per year in the U.S (3). Larger populations require increasing amounts of aid from the aid giver and aid is not infinite. Considering this, it is not so difficult to infer that it is unsustainable for the rich countries to provide the poor with resources or share the available resources with them. Additionally, having become dependent on the financial aid coming from the rich countries, poor nations persistently draw on an overseas aid organisation, such as the world food bank which, as Hardin nicely puts it, diminishes their need only in the short run but increases their need without limit in the long run. People in those nations and their government actually look for ways to benefit from foreign aid momentarily rather than learning how to assist their own people who are suffering from poverty related problems. They lose all incentive to be

\footnotetext{
a $\square$ cmuderrisoglu@yahoo.com
}

Gönderim tarihi: 07.03.2016 • Kabul tarihi: 12.03.2016 
productive because they are given money whenever they are in need. Thus, considering the consequences, it is clear that poverty cannot be alleviated by only giving money to poor people and we need to reevaluate the way the rich help the poor.

It is an undeniable fact that "poverty is not just one more head on the hydra, but the hydra itself that grows all the heads", and is a problem that urgently needs to be eradicated (5). However, the fact that the poor have already received a good deal of aid but problems still persist points to the fact that providing poor nations with financial aid is not the most effective weapon to fight against this "hydra" as Turner (ibid) termed it. In urgent cases, collective action to alleviate poverty is important. Yet, we should not generalise the method of help but should reconsider it by analysing and evaluating the conditions. Wealthy nations need to consider what is in the long-term best interest of the poor. Rich nations need to seek for ways to shape development in the poor world by providing resources and technology to poor nations instead of giving them money and food. Acting on this advice, they should finance programs for improving agriculture in famine-stricken nations and teach them how to increase food production. They should provide trading opportunities for poor countries by opening their markets as well. Poor nations and governments also need to enter wholeheartedly into the process of such a change by first altering their habit of asking for financial aid. They need to "unlearn" what they "know of the past", that is, transform their understanding of belp, which is, according to Rayner, how new beginnings are possible (6).

In conclusion, considering the aforementioned views and examples, it is clear that the issue of poverty is not only a statistical issue, but it is also a human issue. Most agree that the affluent should help the poor, but the way they help should be more thoughtfully considered. Poor nations should be financially supported, particularly in emergency situations to alleviate poverty. Yet, ultimately any long term solution requires poor nations to manage their own challenges.

\section{References}

1. Share the World's Resources [Internet]; Global Poverty and Inequality. (Accessed 07.03.2016). Available from: www.stwr.org/poverty-inequality/overview.html

2. Singer, P. The Singer Solution to World Poverty. The New York Times Magazine, 1999; 60-63. (Accessed 07.03. 2016). Available from: http://www.utilitarian.net/singer/by/19990905.htm

3. Hardin G. Lifeboat Ethics: the Case Against Helping the Poor. Psychology Today [Internet]. 1974 September. (Accessed 07. 03. 2016). Available from: http://www.garretthardinsociety.org/articles/art_lifeboat_ethics_case_against_helping_poor.html

4. BBC News [Internet]. Haiti devastated by massive earthquake; 2010 January 13. (Accessed 07.03.2016). Available from: http://news.bbc.co.uk/2/hi/8455629.stm

5. Turner, F. Make Everyone Rich. The Independent Review: A Journal of Political Economy. 2002; 129136.

6. Rayner, T. Unlearning in Crisis and Change [Internet]. 2010 September 29. (Accessed 07. 03. 2016). Available from: https:// philosophyforchange.wordpress.com/2010/09/29/unlearning-in-crisis-andchange/ 